\begin{tabular}{c|l} 
articles & ANTHROPOLLOS \\
artículos & TEACHINGS: \\
& $\begin{array}{l}\text { The possibility of apprehension of the } \\
\text { "Other" in Journalism }\end{array}$ \\
& $\begin{array}{l}\text { CLÁUDIA LAGO } \\
\text { Anhembi Morumbi University, Brazil }\end{array}$
\end{tabular}

\begin{abstract}
This paper intends to deepen the comprehension regarding the apprehension of the Other in the journalistic field, based on reflections on Anthropology, its specificity and field work. It results from the presupposition that Journalism plays a determining role in the structure and extension of democracy and citizenship and that its social responsibility, commonplace within the values of the field (LAGO, 2003) can only be fulfilled with the incorporation of otherness as a reference. Based on the comparison of how these different fields position themselves with relation to the Other, it seeks to perceive how to incorporate into Journalism elements of the anthropological perspective. Keywords: Anthropology. Journalism. Otherness. Encounter.
\end{abstract}

\title{
ENSINAMENTOS ANTROPOLÓGICOS: a possibilidade de apreensão do "Outro" no Jornalismo
}

RESUMO - Este artigo pretende aprofundar a compreensão sobre a apreensão do Outro pelo campo jornalístico, a partir de reflexões sobre a Antropologia, sua especificidade e o trabalho de campo. Parte do pressuposto de que o Jornalismo exerce um papel determinante na construção e ampliação da democracia e da cidadania e de que sua responsabilidade social, lugar comum dentro dos valores do campo (LAGO, 2003), só pode se concretizar com a incorporação da alteridade como referente. A partir da comparação de como estes campos distintos colocam-se em relação ao Outro, busca perceber como incorporar, ao Jornalismo, elementos do olhar antropológico.

Palavras-chave: Jornalismo. Antropologia. Alteridade. Encontro.

\section{ENSEÑANZAS ANTROPOLÓGICAS: la posibilidad de aprehensión del "otro" en el periodismo}

RESUMEN - Este artículo se propone profundizar la comprensión sobre la aprehensión del otro en el campo periodístico, a partir de reflexiones sobre la antropología, su especificidad y el trabajo de campo. Parte del presupuesto de que el periodismo ejerce un papel determinante en la construcción y ampliación de la democracia y la ciudadanía, y de que su responsabilidad social, lugar común dentro de los valores del campo (LAGO, 2003), solo puede concretarse con la incorporación de la alteridad como referente. A partir de la comparación de cómo estos campos distintos se sitúan en relación al otro, se pretende encontrar la forma de incorporar al periodismo elementos de la mirada antropológica.

Palabras clave: Periodismo. Antropología. Alteridad. Encuentro. 


\section{INTRODUCTION}

Journalism has been supported in its specificity as an important and incontrovertible mechanism within the democratic system that confers prestige and social importance on it, as Neveu $(2005$, p. 8$)$ points out: "Since the emergence of a free press is historically linked to the construction of democratic regimes, Journalism is more than a profession".

This circumstance is at the root, not only of mechanisms from the journalistic field, but of a good part of its self-representations, whether made by journalists or whether they originate from the meta-texts of the press itself, which presents it not just as a place for support of democracy, but also for commitment to the reader (BENETTI and HAGEN, 2009), a commitment which makes journalism furnish quality information to its reader/listener/spectator.

Despite the countless conceptions regarding the term "quality", I would like to adhere to the basic principle that information must maintain a specific relation with reality, so that it does not favor this or that agent (or social group). And that the journalistic product must, in some way, offer a broad and undistorted picture of what is happening.

These presuppositions are at the root of the perception of journalism's social importance, boasted of by journalists, media and other agents of this heterogeneous field with unclear borders, whether they are situated close to the cultural pole or to the commercial pole (BOURDIEU, 1997). And this perspective, this joint repertoire, at least in theory sustains a good part of the justifications for journalism's social role and often produces "enchanted" views of the profession (NEVEU, 2005).

On the other hand, any work, which intends to reflect on the conditions of the real existence of aspects of the relation between journalism and society, should question this perspective, which I intend to do below, starting with the necessary contextualization regarding journalism's social role.

\section{JOURNALISM, SOCIAL RESPONSIBILITY AND PUBLIC INTEREST}

The perspective of journalism's social responsibility is related to the idea that the necessary condition for its primeval existence is public interest. Since Lippmann, with Public Opinion in 1922, this relation has been declared and questioned and although controversial, it is a presupposition that is in the current structure ${ }^{1}$ of the journalistic field. 
In reality, a quick glance makes it possible to verify that the premise of public interest is contained in countless definitions, such as that formulated by F. Fraser Bond, for whom

The word journalism means nowadays all the ways, in which and through which news and their comments get to the audience. All world events, as long as the audience is interested in them, and every thought, action and idea these events stimulate, constitute basic material for the journalist (BOND, 1962, p. 15, highlighted by myself).

Subjacent to this definition, Fraser Bond identifies journalism's duties: independence, impartiality, precision, honesty, responsibility and decency. This list of ideal obligations infers that the practice of journalism is related to the disclosure of truth and to the capability for assuring the information needed by the society.

A good part of the theoreticians who have sought to define journalism in the beginning of the research work share this premise, as does Luiz Beltrão, in Brazil:

(...) journalism is information of current events, duly interpreted and transmitted daily to the society, for the purpose of diffusing knowledge and guiding public opinion, in the sense of promoting the common welfare (BELTRÃO, 1992, p. 67).

This comprehensive universe is fully detailed by UNESCO when in the 1950s it focused on the need for a new order in communication:

The peoples' welfare depends on their freely and judiciously adopted decisions. The value of these decisions depends in turn on the degree of information of the citizenry and the latter are only informed to the extent that the facts and events are reported to them in an exact and complete way. The quality of the information depends on the journalist's comprehension, knowledge, professional traits and sense of responsibility (UNESCO apud MEDINA, 1982, p. 35).

Although journalistic praxis is not necessarily linked to these presuppositions, but rather to a pragmatic relation with the profession, based on market values, this set of presuppositions persists, forming a romantic ethos, which is based on vocation, mission and social responsibility (LAGO, 2003). This ethos, shared by various agents, is considered to be one of the bases of credibility itself, which in turn is based, as authors such as Traquina (1993, p. 164) have specified, on a kind of "gentlemen's' agreement", in other words the tacit supposition between journalists and readers that the 
former will not "overstep the border which separates reality from fiction" allowing the "reading of the news as a table of contents of reality $(\ldots)^{2 "}$.

Underlying theses postulates, the premise appears that the quality of journalistic information is an inherent part of the democratic system and fundamental for the exercising of citizenship ${ }^{3}$, since the complete fulfillment of the role of citizen

[...] lacks intelligible, complete and contradictory information, which reflects the largest possible number of social life dimensions and is not polarized only in the institutional discourses, does not identify the normal ways as trivial or banal nor reduces society to their rulers (NEVEU, 2005, p. 115).

It is clear here that journalism's social responsibility and the support of the public interest cannot be limited to furnishing the information, which supposedly interests the public. As a social action inherent in the democratic system, the moral obligation falls on journalism to allow the multiplicity of opinions of the society to be foreseen.

For Neves (2005, p. 135), "the democratic ideal requires a journalism of information economically and culturally accessible to all and producer of reflection on the political challenges". The necessary condition for the existence of this type of journalism is based on three points of support: the State, pluralism and the introduction of scientific knowledge "in the center of the public debate". In relation to pluralism, the author reinforces the view that this should be political, but also sociological. As sociological pluralism he specifies the need for the journalist to be "attentive to the various experiences of society and of its expressions", knowing how to "pick them up where they have little capability for making themselves heard institutionally" and giving them "voice in order to stimulate the reflection of vaster publics".

\section{PLURALISM IN JOURNALISM: TRACES OF AN (IM)POSSIBILITY}

At this moment, an equation that seemed to be simples starts to reveal itself as much more complex. Recollecting: in the corollary of values and representations of the current journalistic field is its social responsibility, which links it to concepts such as public interest, democracy and citizenship. Nevertheless, in order for it to follow this path, journalism must be plural and not just follow the old formula of allowing different points of view on a specific topic 
to occupy the same editorial space. The idea of Pluralism is much more profound and implies contemplating and incorporating the Other, this abstraction that deserves to be explained.

Resende (2008), analyzing documentaries which proposed to represent the Other ${ }^{4}$, observes the ethical dilemmas existing in the difficulty of representing him in his difference, and in the insufficiency of a journalistic perspective reduced to a "didactic and/ or opinionative" dimension.

This dimension, however, seems to pertain to the majority. Aidar and Bairon (2007), commenting on the methodology of the Print Media Research Group of the Pontifical Catholic University of São Paulo (PUC/ SP), explain that the work consists of the development of "strategies for analysis of the figures of the Same and of the Other in the weekly media", constructing based on these "modes of intervention in terms of a project of education for the media" (AIDAR and BAIRON, 2007, p. 251). As figures of the Other, the researchers identify the figures of otherness, which, in the case of the weekly media, "are always condensed to the Same", and never are understood in "their radical otherness". Or, forming a conception:

\begin{abstract}
We call 'Same' the series of cultural and political landscapes, together with their values, made euphoric by the media and homologous to the average importance of their publics. We call 'Other' the series of cultural and political landscapes, together with their values, from which the media establish relative distances, calculated, homologous to the withdrawal that their audiences maintain. In the face of the Other it is necessary to protect oneself, describing him as exotic (...), it is necessary to hide him from the searchlight, leave him in the margins, thus he can be assimilated, admitted or segregated; (...) (AIDAR and BAIRON, 2007, pp. 252-3).
\end{abstract}

More often, this Other is transformed into the enemy, as the authors' analysis of the covers of Veja magazine identifies. Although the research refers to weekly magazines, I believe we can retain its results and expand them to cover the media in general. In this way the reductionisms ${ }^{5}$ related to the representations of the Other and, more than this, the mistrust and even hostility with relation to everything which does not form part of the potential universe of the ideal public (the middle and upper classes of the population) can be perceived as the rule and not as the exception.

This diagnosis is supported by Resende (2009) who expands it to the journalistic narrative as a whole: 
In the journalistic narrative, the authoritarian way of narrating stories is maintained and, in a certain way, with more aggravating circumstances, because it is presented in a veiled manner. Enveloped in reality and truth, besides bringing impartiality and objectivity as elements, which produce meanings, the traditional journalistic discourse - which encounters epistemological legitimacy - makes available to the journalist scarce resources for narrating everyday events (RESENDE, 2009, p. 36).

The author observes, however, the feasibility of working in the gaps in the discourse and promoting what he calls the "encounter", which I interpret as the possibility of accepting otherness in a narrative manner.

Nevertheless, this perspective runs into difficulties that do not only refer to journalism's narrative structure, but before this. In my opinion, the perspective is made more difficult by the very characteristic of the journalist agent, formed primarily within the middle and upper classes of the population, carrying this class habitus and the predispositions inherent in it, besides its formation along a field that structurally estranges and disqualifies otherness. If we think of the Bourdian metaphor of the specific eyeglasses (BOURDIEU, 1997) which journalists utilize, which make them see what they see in certain ways, how can one act to change theses eyeglasses for those of other people?

Constructing a type of Journalism capable of incorporating the Other in his plenitude is a challenge, which runs up against not only the structure of the field but also the training of the journalists themselves so that they perceive and are contaminated by this necessity. In this sense, I agree with Aidar and Bairon (2007) when they postulate that an education for the media in this direction is more than anything a deconstruction of the existing arrangements which prepare journalists in general for not reflecting on the issue of otherness.

On the other hand, I believe that it is not enough for us to reflect on the problematic of the Other relating it only to the journalistic discourse, despite the importance of doing this. It is necessary to join this with a previous reflection that refers to the journalistic field's structural impossibility of perceiving the world beyond its conductive grammar (Resende 2008). Because, if it is true that the possibility of dialogue is established by the narrative, or by the possible "gaps" in that narrative, the possibility of seeing gaps stems from the incorporation of a perspective which is not in the professional canons, but rather outside them. 
Here I believe Neveu's (2005) postulate mentioned earlier is applicable: the need for incorporating scientific knowledge into Journalism. And, in the case in question, a very specific knowledge: Anthropological knowledge.

\section{ANTHROPOLOGY AS THE LOCUS TO DEVELOP REFLECTIONS ABOUT THE OTHER}

Anthropology has much to teach us in terms of the perception of the Other. Not so much because it is the locus for managing otherness as a social scientific construction, but because it has deposited in its field an old, extensive and profound reflection on the limitations when what is in play is the confrontation between different elements.

This reflection is inherent in the birth of Anthropology, which springs from an equation that sought to encounter, through diversity, the generality of a Humanity created by the Enlightenment, Or as LéviStrauss stated: "an undertaking (anthropology) which renews and atones for the Renassaince, with the purpose of leading humanism to attain the extent of humanity" (LEVI-STRAUSS, 1975, p. 222).

In a singular encounter between the anthropologist and the "native", a "confrontation of differences" (PEIRANO, 1992), chemistry occurs which produces anthropological knowledge. This equation developed around the experiences of researcher and researched yields Anthropology (...) its distinct character among the other fields of knowledge: of all the sciences, it is undoubtedly the only one to make a means of objective demonstration out of the most intimate subjectivity (PEIRANO, 1992, p. 216).

In the anthropological encounter from early on an attempt was made to "apprehend the point of view of the natives, their relationship with life and their view of their world" (MALINOWSKI, 1976, p. 38). This ideal situation, that is to say, that of the encounter with a culturally (and geographically) distant Other, made by means of field work in which the observer should try to apprehend the point of view of the person observed, together with the internalization of the concept of Culture ${ }^{6}$ were the basis for the organization of Anthropology as an autonomous subject.

Another characteristic, forged in the clash between an observer and societies then understood as "simple", was the quest to achieve a totality. Native societies were totalities, which could be reached by 
means of total social events, such as the Kula of Malinowski.

It is obvious that the guiding points of what Anthropology is cannot be summarized so synthetically. I have selected here some characteristics that are recurring in discourses produced by subjects who are identified as anthropologists. In one way or another, on identifying anthropological work, we are using notions that deal with or are referred to in descriptive fieldwork, which go back to a tradition that sought out societies in their entirety, which presupposes the acquisition of knowledge through a singular experience with otherness, with the Other. "After all, everything is based on otherness in Anthropology: an anthropologist exists only when there is a native transformed into informer. And there is data only when a process of empathy flows from one side to the other" (DaMATTA, 1978, p. 34).

The relation with the Other, in the context of fieldwork that throws the anthropologist into a world different from his own, within which he is often at the mercy of this undecipherable world, produces very intense sensations:

\begin{abstract}
His living and working conditions separate him physically from his group during long periods; due to the brutality of the changes to which he is exposed, he acquires a kind of chronic uprooting, he will never again feel "at home" anywhere and will remain psychologically mutilated" (LEVI-STRAUSS, 1993, p. 32).
\end{abstract}

This entire process will result in ethnography, a descriptive record of the life and social organizations of the natives. And despite the loss of the traditional subject of Anthropology (isolated societies), of the sensation that there are no totalities, that it is not enough to go to the field in order to think about otherness, that the researcherresearched relation will never again be the same, from the growing and insistent concern for objects within urban societies,

[...] field work involving numerically small societies (or spatially circumscribed sectors of larger societies) with a non-western cultural tradition, and its typical result, the ethnographic monograph, continue to be the classic reference of anthropology and, I dare say, the root of its autonomy as a discipline (VIVEIROS DE CASTRO, 1990, p. 2).

Despite this, already in the 1960s, in response to a new configuration of the traditional anthropologist/native, subject/object binomial, at the same time that the need for rethinking the discipline or for incorporating within the permissible domains of Anthropology the study of complex societies was being discussed, new concepts 
were developed, more linked to the anthropological method than to its object. And reflection was intensified with regard to the relations of power ${ }^{7}$ within the field, which placed the anthropologist and the native in opposite poles.

When Anthropology turns to the study of urban societies and begins to apply its meticulous, detailing perspective both to groups coming from the lower classes as well as to those from the middle and upper classes, together with the already traditional reflections on the power of some and the lack of power of others, reflections are added regarding the possibility or impossibility of carrying out anthropological work in this new universe of analysis.

Despite this, anthropological research regarding the lower classes puts on the agenda mainly the relations of power that involve the encounter with the Other, whether the relations are with the researcher or with the society in which the groups involved are included.

On the other hand, researchers who choose their subjects from among the groups with greater purchasing power tend to confront issues of another kind, such as the way in which one can apprehend an Other who is not so clearly constituted as such, an Other who is apparently the Same. The formula "transforming the familiar into exotic and the exotic into familiar" (VELHO, 1987) is an attempt to respond to this difficulty in obtaining the necessary strange discovery which makes the understanding of the difference spring out and which guides a vast universe of research involving urban groups.

However, this migration from research carried out traditionally involving peoples with marked otherness to closer social groups (even though separated by the social classes) creates problems of a more unusual type.

In a classic text on the anthropological method, Eunice Durham (1986) points to two trends in urban research works: those whose subjects are generally needy, marginalized populations and which utilize traditional methods of ethnographic research (accompanying the group, observation in loco of their everyday life), and research works which give importance to the symbolic dimension, whose groups analyzed are the classes with greater purchasing power. Drawing a parallel between the participant observation performed in the traditional (or ideal) field situation and the participant observation performed with groups in the cities, Durham states: 
[...] the participation (in the first case) is more objective than subjective - the researcher lives together constantly with the population studied, remaining, however, a foreigner (even though well accepted)... oral communication is frequently subordinated to observation of the behavior manifested. In research done in the cities, within a cultural universe common to the researcher and to the subject of the research, the participation is more subjective than objective... [...]But (the researcher) seeks, in the symbolic interaction, identification with the values and aspirations of the population he is studying. [...] purely oral communication predominates, obscuring the observation of behavior (...) (DURHAM, 1986, p. 26).

This subjective identification, according to Durham, can lead the researcher to see the universe researched based on the native categories, a problem aggravated in dealing with clearly fragmented societies, in which the life experience of the groups does not succeed in recovering the variety of social life.

The foregoing allows one to foresee the fundamental place occupied by reflection on the relation with otherness, a relation that is made real in the fieldwork of the anthropologist. The fieldwork, which places anthropologist and "native" face to face, is so crucial for the anthropological project that many times Anthropology itself is summed up by it. Indeed, this part is extremely significant for the discipline, because it is during the fieldwork that the contact between subject/object is established. An unequal contact, permeated by lack of comprehension, which most of the time will not result in a full encounter (GEERTZ, 2001), but which contains this possibility, this utopia.

And it is this scope that confers on Anthropology a specific arsenal with full conditions for an encounter with the Other. A reflective repertoire with questions, dilemmas, paradoxes and conflicts inherent in this confrontation/encounter which, if we compare it, can emphasize the absence of any concern in this connection for Journalism, a place in which the Other is given and constructed $a$ priori within quite clear stereotypes: either criminalized (most of the time) or glamorized in narratives which perceive him out of context ${ }^{8}$.

\section{CAN JOURNALISM AND ANTHROPOLOGY BE COMPLEMENTARY?}

Research works in journalism sometimes utilize the anthropological method, without necessarily reflecting on it (LAGO, 2007). And journalistic praxis skirts around any incorporation of anthropological questions, despite the similarities between the two universes. 
Anthropology as well as Journalism opens the possibility of constructing narratives regarding otherness, which they suppose are true, in the sense of pointing to correspondences between life as it is and life portrayed by these narratives. Both utilize for this informers (in one case) and sources (in the other case). The latter in turn are identified as those who can furnish trustworthy information on what is observed. Anthropology resorts profoundly to observation, but also to discourse; Journalism constructs its narratives taking as a basis mainly the discourse woven by those involved, but also observes. Both interfere in the relations that they portray, but while Anthropology currently identifies as a determining factor of its work the subjectivity originating in the relations of confrontation/ encounter, Journalism adheres to the notion that there is objectivity possible in the relationship with its sources.

And basically, both need to work within a dialectic relation of approach to and distancing from what they try to portray. For Anthropology, the distancing, the transforming the familiar into exotic (in the case of urban anthropology), which enables the construction of a specific knowledge. For Journalism the mistrust, emphasized in colleges or newsrooms, as the only guarantee for not incorporating as a-critical truth what the informers say.

Despite the similarities, the products of the relations established in the journalistic and anthropological fields are infinitely diverse, obviously in form, as they could not fail to be, but mainly in essence. While Anthropology involves the need for apprehending, comprehending and accepting the Other, Journalism operates in the opposite direction.

In Journalism, what the anthropologist Magnani (2002) identifies in studies of the cities is repeated: the absence of a certain type of social actor and the predominant role of other actors:

the dynamics of the city are credited in a direct, immediate way to the capitalist system, changes in the urban landscape, proposals for intervention (requalification, recycling, restoration); institutional alterations do not go beyond adaptations to the phases of capitalism which is erected, in the capacity of an independent variable, as the last and total explanatory dimension (...) In this case, when social actors appear, they are representatives of capital and of the market forces: financiers, real estate agents, private investors. Characters such as "cultural stimulators" - consultants, architects, artists and other intellectuals - are also present but at the service of the interests of capital (...) The inhabitants themselves, who in their multiple networks, forms of sociability, life styles, dislocations, conflicts, etc., constitute the element that definitively gives life 
to the metropolis, do not appear, and when they do, it is in the capacity of the passive party (the excluded, the plundered) of the entire intricate urban process (MAGNANI, 2002, online).

Journalism chooses as a reference the macro structure and the sources which are related to it, And on doing this, it despises a "range of practices which are not possible in the key for reading" (MAGNANI, $2002)^{9}$ placed by Journalism. A key for reading which disqualifies the Other and makes him invisible in his complete otherness.

Anthropology, upon recovering the Other's dimension, on incorporating these actors and their social practices, can contribute to [...] introducing other points of view (...) beyond the "competent" perspective which decides what is right and what is wrong and beyond the perspective and interest of power, which decides what is appropriate and profitable (MAGNANI, 2002, online).

The researcher's proposal, directed at studies which underlie policies regarding urban space, in my opinion is appropriate for Journalism, insofar as it proposes to change the focus "from far off and outside" to a perspective "close up and inside", precisely the anthropological perspective:

Thus, what is initially proposed with the ethnographic method applied to the city and its dynamics is to recover a perspective from close up and inside capable of identifying, describing and reflecting on aspects excluded from the perspective of those focuses which, for the purpose of contrast, I described as from outside and far off (MAGNANI, 2002, online).

But what makes this type of perspective possible? I believe that as applied to Journalism, the effort would be in the direction of removing the constituted perspective from the center, making it permeable to points of view, angles, life experiences, the possibility of being affected by the Other, instead of trying to perceive him by means of the current normative grammars which are contained in the manuals and inside the newsrooms (with extremely rare exceptions). It would be incorporating and accepting the anthropological presupposition that journalists, sources and groups portrayed,

[...] participate on the same plane: that of the "basic phenomena of the life of the spirit" (Levi-Strauss, 1971, p. 28). Both are endowed with the same cognitive processes that allow them, on a more profound level, to enjoy a communion beyond the cultural differences. After all, "the thousands of societies which exist or existed on the surface of the earth are human and for this reason we participate in them in a subjective way, we could have made up part of them and therefore, we can try to comprehend them as if we were part of them" (idem, p. 26) (In MAGNANI, 2002, online). 


\section{CONCLUSION: WE NEED MEDIA EDUCATION}

The journalistic field maintains in its framework of values concepts such as that of social responsibility, public interest, commitment to democratic values and to citizenship.

However, its praxis lacks appropriate tools for full compliance with this conceptual horizon, starting with a structural impossibility to apprehend and accept the Other, in all his otherness, without reductionisms and stereotypes. Without this acceptance, there is no effective democracy, nor full citizenship.

I think that this structural impossibility results on a lesser scale from the production routines, from the constraints to which the newsrooms are subjected, than from the sharing of specific values inherent in the field that exclude the different, circumscribe it and do not fully perceive it. I believe that a tacit agreement reigns in Journalism involving both companies as well as journalists, that erase from the scene all that which cannot be comprehended through the lens of what we can call "the Same".

Journalism lacks in general an inclusive perspective, contaminated by the possibility of understanding and accepting views of the world radically different from those derived from projections on the ideal public (the urban middle and upper classes).

How can we instill this perspective? The task is not easy and perhaps not possible, since Anthropology itself, the place where the idea of otherness was born, struggles with dilemmas inherent in this perspective, since the beginnings of its institution as an autonomous field, during the XIX century.

Nevertheless, this (im)possibility must become a horizon, and perhaps a step in this direction would be the incorporation of the anthropological reflexive framework regarding the moral dilemmas of field work (GEERTZ, 2001) into journalists' conceptual universe ass part of a project of education for the media which, as Aidar and Bairon (2007) postulate, has implicit the deconstruction of the mechanisms currently in use.

\section{NOTES}

1 What is natural now and forms part of the field's structure was not always this way. For example, objectivity became a value starting 
with the influence of Anglo-Saxon commercial journalism, produced on a large scale and concerned with satisfying the needs of the advertisers (circulation), not with the dissemination of this or that political opinion (NEVEU, 2005).

2 This agreement often seems to me to be overestimated on the part of the journalists, as if the public never mistrusted what the communication media disseminate.

3 The relation between journalism, democracy and citizenship, and that of the press as the fourth power and related topics have already been exhaustively analyzed from various angles and by various authors. I have not reproduced aspects of this discussion that goes beyond the scope of this work.

4 In this case the inhabitants of the slums involved in drug trafficking exposed in Falcão - os meninos do tráfico and Notícias de uma guerra particular.

5 We can consider this affirmation as variable. The supposed public to whom the media product is directed could influence the way in which the latter deals with the issue of otherness. Nevertheless, most of the time what we can observe in terms of media in general (and journalism in particular) is the prevalence of stereotypes with respect to this Other, who hardly appears in his fullness as a subject with rights and multiple facets.

6 The concept of Culture is not consensual even among anthropologists, and hundreds of possible definitions exist. It is these intuitive concepts that those versed in the field understand but do not necessarily express.

7 A great part of the consistent criticism regarding the question of power in the field originates in the work of the so-called post-modern scientists who rebel against the role of the author in the ethnographic text, mainly with reference to classic ethnography, carried out by western anthropologists in contact with natives of geographically and culturally distant lands. As the critics observe the writing of the text, a good number of them try to subvert the relations by means of the text itself, which on the other hand was considered to be insufficient by several later critics.

8 Like the stories about the success of exponents of the lower classes who "succeeded in making it", or the small televised flashes about the cultural part of the slums - most of the time identifying the groups 
organized around NCOs, the majority structured outside the slums.

9 The author refers to the key for the reading of a certain type of politics, but I believe we can extrapolate the proposition to journalism.

\section{REFERENCES}

AIDAR, José Luiz Prado; BAIRON, Sérgio. A Construção do Outro na Mídia Semanal. In: LACO, Cláudia e BENETTI, Marcia. (orgs.) Metodologia de pesquisa em jornalismo. Petrópolis, Vozes, 2007.

BELTRÃO, Luiz. Iniciação à filosofia do jornalismo. 2 ed. São Paulo: Edusp, 1992.

BENETTI, Marcia; HAGEN, Sean. Jornalismo e Imagem de si: o discurso institucional das revistas semanais. Belo Horizonte: Anais do $18^{\circ}$ Encontro Anual da Compós, GT Estudos de Jornalismo, 2009.

BOND, Fraser F. Introdução ao Jornalismo. Rio de Janeiro: Agir Editora, 1962.

BOURDIEU, Pierre. Sobre a Televisão. Rio de Janeiro: Jorge Zahar, 1997.

DAMATTA, Roberto. O ofício do etnólogo, ou como ter anthropological blues. In: NUNES, Edson de Oliveira (org.). A aventura sociológica. Rio de Janeiro: Zahar, 1978.

DURHAM, Eunice. A pesquisa antropológica com populações urbanas: problemas e perspectivas. In: CARDOSO, Ruth (org.). A aventura antropológica. São Paulo: Paz e Terra, 1986.

GEERTZ, Clifford. Nova Luz sobre a Antropologia. Rio de Janeiro: Zahar, 2001.

LAGO, Cláudia. De romântico e de louco... o Ethos romântico no jornalismo.

Recife: XII Encontro Anual da Compós, GT Estudos de Jornalismo. 2003.

Antropologia e Jornalismo, uma questão de método. in: LAGO, Cláudia e BENETTI, Marcia. (orgs.) Metodologia de pesquisa em jornalismo. Petrópolis, Vozes, 2007.

LEVI-STRAUSS, Claude. A crise moderna da antropologia. Revista de Antropologia, São Paulo, vol. 10, June and december, 1962. 
1993.

Tristes Trópicos. Lisboa: Edições 70,

MAGNANI, José Guilherme Cantor. de Perto e de dentro: notas para uma etnografia urbana. Revista Brasileira de Ciências Sociais vol.17 no. 49 São Paulo: Junho de 2002. Disponível em http://www.scielo.br/scielo. php?pid=S0102-69092002000200002\&script=sci_arttext .Acesso em 10 de fevereiro de 2010.

MALINOWSKI, Bronislaw. Argonautas do pacífico ocidental. São Paulo: Abril Cultural, 1976.

MEDINA, Cremilda. Profissão Jornalismo: responsabilidade social. Rio de Janeiro: Forense universitária, 1982.

NEVEU, Érik. Sociologia do Jornalismo. Porto: Porto Editora, 2005.

PEIRANO, Mariza G.S. A favor da etnografia. Brasília: unB, 1992, xeroxed lecture notes.

RESENDE, Fernando. A narratividade do discurso jornalístico: a questão do outro. São Bernardo do Campo: Anais do $6^{\circ}$ Encontro Anual da SBPJor, 2008.

O Jornalismo e suas Narrativas: as Brechas do discurso e as Possibilidades do Encontro. Revista Galáxia, São Paulo, n. 18, p.3143, dec. 2009.

TRAQUINA, Nelson. As notícias. In: TRAQUINA, Nelson (org.) Jornalismo: questões, teorias e "estórias". Lisboa: Veja, 1993.

VELHO, Gilberto. Individualismo e cultura: notas para uma antropologia da sociedade contemporânea. Rio de Janeiro: Zahar, 1987.

CLAUDIA LAGO is professor at the University Anhembi Morumbi (UAM). She is PhD in Communication from São Paulo University (USP) and Master Degree in Anthropology from the Federal University of Santa Catarina (UFSC). 